\title{
Mechanism of apoptosis induction in human hepatocellular carcinoma cells following treatment with a gecko peptides mixture
}

\author{
YING JIN $^{1 *}$, LENG-XIN DUAN $^{1}$, XIN-LI XU ${ }^{2 *}$, WEN-JING GE ${ }^{1}$, RUI-FANG LI ${ }^{1}$, \\ XIANG-JUN QIU ${ }^{1}$, YING SONG ${ }^{3}$, SHAN-SHAN CAO ${ }^{4}$ and JIAN-GANG WANG ${ }^{1}$
}

\begin{abstract}
${ }^{1}$ The Key Laboratory of Pharmacology and Medical Molecular Biology, Medical College, Henan University of Science and Technology, Luoyang, Henan 471003; ${ }^{2}$ Department of School Infirmary Pharmacy, South China University of Technology, Guangzhou, Guangdong 510000; ${ }^{3}$ Department of Pharmacy, The First Affiliated Hospital of Henan University of Science and Technology; ${ }^{4}$ Department of Pharmacy, The Third Affiliated Hospital of Henan University of Science and Technology, Luoyang, Henan 471003, P.R. China
\end{abstract}

Received January 19, 2016; Accepted April 15, 2016

DOI: $10.3892 /$ br.2016.664

\begin{abstract}
The aim of the present study was to investigate the apoptotic effect and molecular mechanisms of gecko peptides mixture (GPM) on the human liver carcinoma HepG2 cell line in vitro. The methylthiazolyldiphenyl-tetrazolium bromide (MTT) assay was performed to identify the dose- $(0.10,0.15,0.20,0.25$ and $0.30 \mathrm{mg} / \mathrm{ml})$ and time-dependent (24, 48 and $72 \mathrm{~h})$ inhibitory effect of GPM on HepG2 cells and their proliferation. Hoechst 33258 staining was carried out to detect the nuclear change coupled with apoptosis induced by GPM. Western blotting was used to evaluate apoptosis-related protein expression changes induced by GPM, including caspase, cytochrome $c(\mathrm{Cyt} c)$ and apoptosis-inducing factor (AIF). MTT results showed that GPM significantly inhibited the proliferation of HepG2 cells in a dose- and time-dependent manner. Hoechst 33258 staining demonstrated that GPM induced typical apoptotic morphological changes, while western blotting analysis revealed that GPM increased caspase-3, caspase-9, Cyt $c$ and AIF protein expression levels in HepG 2 cells treated with 0.06 or $0.08 \mathrm{mg} / \mathrm{ml}$ for $24 \mathrm{~h}$. In conclusion, GPM could induce apoptosis by activating the intrinsic mitochondrial apoptotic pathways.
\end{abstract}

Correspondence to: Dr Jian-Gang Wang, The Key Laboratory of Pharmacology and Medical Molecular Biology, Medical College, Henan University of Science and Technology, 31 Anhui Road, Luoyang, Henan 471003, P.R. China

E-mail: ylwjg@163.com

*Contributed equally

Abbreviations: GPM, gecko peptides mixture; Cyt $c$, cytochrome $c$

Key words: gecko peptides mixture, human hepatocellular carcinoma, apoptosis, mitochondrial pathway

\section{Introduction}

Hepatocellular carcinoma (HCC) is a primary malignancy of hepatocytes, accounting for $80 \%$ of all primary liver cancers. Globally, HCC is ranked as the fourth leading cause of cancer-related fatalities (1). Patients with chronic liver diseases associated with hepatitis B virus or hepatitis $\mathrm{C}$ virus infections frequently develop HCC (2). There has been an improvement in surgical techniques and the development of several non-surgical treatment modalities; however, improvement for the extremely poor prognosis of HCC patients remains limited (3).

Extensive investigation of apoptosis, also known as programmed cell death, in the past decades has highlighted this process as a suitable method for cancer therapy $(4,5)$. However, numerous drugs with apoptotic effects are currently limited for cancer therapy due to the side effects. Therefore, identifying novel and reliable therapeutic agents that can efficiently induce cancer cell apoptosis in the treatment of patients with $\mathrm{HCC}$ is important.

Recently, traditional Chinese medicine has an important role in the treatment of malignant tumors due to its significantly ameliorated effects and lower side effects (6). Gecko, one of the popular traditional Chinese medicines, has been used as a crude drug to treat malignant tumors in the clinical practice (7-9). Gecko crude peptides and gecko ethanol extract can induce apoptosis in human HCC cells and exert antitumor activity in ascites $\mathrm{H} 22$-bearing mice, which was demonstrated in our previous studies $(10,11)$. The aim of the present study was to examine the apoptotic effect and underlying mechanism of gecko peptides mixture (GPM) in human liver carcinoma HepG2 cell lines in vitro.

\section{Materials and methods}

Medical materials and reagents. Gecko japonicus was purchased from Bozhou Yonggang Medicinal Herbs Factory Co., Ltd. (Anhui, China). The human HCC cell line HepG2 was presented by Medical Science Research Institute of Henan (Henan, China). 
Methylthiazolyldiphenyl-tetrazolium bromide (MTT) and Hoechst 33258 were purchased from Sigma (St. Louis, MO, USA). The Caspase Activity Assay kit was purchased from Beyotime Institute of Biotechnology (Beijing, China). The primary antibody against apoptosis-inducing factor (AIF) was purchased from Boster Inc. (Wuhan, Hubei, China), and the $\beta$-actin antibody was purchased from Proteintech (Wuhan, Hubei, China). The primary antibody against cytochrome $c$ (Cyt $c$ ) and secondary antibody conjugated to mouse or rabbit were purchased from Zhongshan Golden Bridge Biotechnology Co., Ltd. (Beijing, China).

The microplate reader was the product of BioTek Instruments, Inc. (Winooski, VT, USA). The BX41 fluorescence and inverted microscopes were the product of Olympus (Tokyo, Japan).

Preparation of GPM. Gecko powders $(100 \mathrm{~g})$ were mixed with $400 \mathrm{ml}$ double-distilled water and made into a homogenate. Following centrifugation at $5,600 \mathrm{x}$ g for $5 \mathrm{~min}$, the precipitation was collected and soaked in $400 \mathrm{ml}$ of $55 \%$ ethanol solution. The supernatant was obtained following centrifugation at 5,600 $\mathrm{x}$ g for $5 \mathrm{~min}$, and was evaporated under reduced pressure at $55^{\circ} \mathrm{C}$. Subsequently, yellow powders were collected following freeze-drying of the residue liquid. Gel filtration chromatography (Sephadex G-25) was used to purify the yellow powders, and ultimately, the GPM was collected.

Cell culture and morphological observation. HepG2 cells were cultured in Dulbecco's modified Eagle's medium supplemented with $10 \%$ fetal bovine serum, $100 \mathrm{U} / \mathrm{ml}$ penicillin and streptomycin at $37^{\circ} \mathrm{C}$ in a humidified $5 \% \mathrm{CO}_{2}$ incubator. The culture medium was replaced every 2 days and the cells in the logarithmic growth phase were used for the following experiments. HepG2 cells $\left(3.0 \times 10^{4}\right.$ cells $\left./ \mathrm{ml}\right)$ were incubated with various concentrations of GPM for $24 \mathrm{~h}$. The cells were observed and images captured by an inverted phase contrast microscope to detect the morphological changes.

MTT assay. HepG2 cells were seeded in a 96-well plate at a density of $6.0 \times 10^{3}$ cells/well. Different concentrations of GPM and $0.003 \mathrm{mg} / \mathrm{ml}$ fluorouracil (5-Fu) were added to each well. After incubation for 20, 44 and $68 \mathrm{~h}$, respectively, $20 \mu \mathrm{l}$ of the MTT reagent $(5 \mathrm{mg} / \mathrm{l})$ was added per well and incubated for another $4 \mathrm{~h}$. The supernatant was replaced by $200 \mu 1$ dimethyl sulfoxide and the absorbance (A) at $490 \mathrm{~nm}$ was measured with an ELX800 Universal Microplate reader. The cell proliferation inhibition rate (IR) was as follows: $\mathrm{IR}=\left(1-\mathrm{A}_{\mathrm{GPM}} / \mathrm{A}_{\text {control }}\right) \times 100 \%$.

Hoechst 33258 staining. Following overnight culturing in a 6-well plate, the HepG2 cells were treated with various concentrations of GPM $(0,0.06$ or $0.08 \mathrm{mg} / \mathrm{ml})$ and $0.003 \mathrm{mg} / \mathrm{ml}$ 5 -Fu in fresh culture medium at $37^{\circ} \mathrm{C}$ for $24 \mathrm{~h}$. The cells were washed twice with phosphate-buffered saline (PBS) and stained with Hoechst 33258 staining solution $(10 \mu \mathrm{g} / \mathrm{ml})$. After $15 \mathrm{~min}$ of incubation in the dark, the cells were washed twice with cold PBS and were examined with the fluorescence microscope.

Caspase activity analysis. Determination of caspase- 3 and caspase- 9 activity was performed with the Caspase Activity

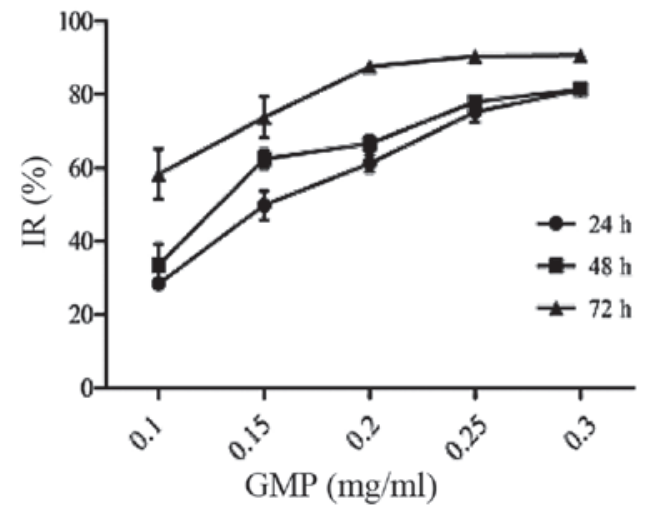

Figure 1. Inhibitory effect of the GPM on HepG2 cell proliferation. GPM, gecko peptides mixture; IR, inhibitory rate.

Assay kit, following the manufacturer's protocol. After exposure to several concentrations of GPM $(0,0.06$ or $0.08 \mathrm{mg} / \mathrm{ml})$ and $0.003 \mathrm{mg} / \mathrm{ml} \mathrm{5-Fu}$ for $24 \mathrm{~h}$, the cells were harvested and resuspended in lysis buffer. Subsequently, the cells were incubated in the lysis buffer for $20 \mathrm{~min}$ and were centrifuged at $16,000 \mathrm{x}$ g at $4^{\circ} \mathrm{C}$ for $3 \mathrm{~min}$. Supernatants were collected and protein levels were determined by the Bradford method, and caspase- 3 and caspase- 9 activities were measured by reaction buffer (containing dithiothreitol) and caspase substrate peptides Ac-DEVD-pNA and Ac-LEHD-pNA, respectively. The obtained values at optical density at $405 \mathrm{~nm}$ were expressed as: $\mathrm{A}_{\mathrm{GPM}} / \mathrm{A}_{\text {Control. }}$

Western blot analysis. HepG 2 cells were treated with GPM $(0$, 0.06 or $0.08 \mathrm{mg} / \mathrm{ml}$ ) and $0.003 \mathrm{mg} / \mathrm{ml} \mathrm{5-Fu}$ for $24 \mathrm{~h}$, respectively. Briefly, the cells were treated with lysis buffer on ice for $30 \mathrm{~min}$, and were centrifuged at $13,000 \mathrm{x}$ g for $30 \mathrm{~min}$ at $4^{\circ} \mathrm{C}$. The protein concentration was determined by Bradford method. Proteins were separated by $12 \%$ SDS-PAGE and were transferred to PVDF membrane. The PVDF membrane was blocked with 5\% non-fat dry milk in PBS for $1 \mathrm{~h}$ at $37^{\circ} \mathrm{C}$, washed 3 times with Tris-buffered saline containing $0.1 \%$ Tween-20 (TBST) for $15 \mathrm{~min}$, and was followed by incubating with the primary antibodies: Caspase-3 (cat. no. sc-7148; 1:200, polyclonal rabbit anti-human), caspase-9 (cat. no. sc-8355; 1:200, polyclonal rabbit antihuman), Cyt $c$ (cat. no. sc-13156; 1:500, monoclonal mouse anti-human), AIF (cat. no. PB0388; 1:200, polyclonal rabbit anti-human) and $\beta$-actin (cat. no. 66009-1-Ig; 1:5,000, monoclonal mouse anti-human) overnight at $4^{\circ} \mathrm{C}$. Subsequently, the samples were washed with TBST for $30 \mathrm{~min}$, and the membrane was incubated with the corresponding secondary antibodies [goat anti-rabbit immunoglobulin $\mathrm{g}(\mathrm{IgG}) /$ horseradish peroxidase (HRP); cat. no. ZDR-5306; 1:5,000; and goat anti-mouse IgG/HRP; cat. no. ZDR-5307; 1:5,000] for $1 \mathrm{~h}$. Chemiluminescence was detected with ECL Plus (Beyotime Institute of Biotechnology).

Statistical analysis. The experimental data are represented as mean \pm standard deviation. The differences between the groups were examined with one-way analysis of variance using the SPSS 19.0 system (IBM Corp., Armonk, NY, USA). P<0.05 was considered to indicate a statistically significant different. 


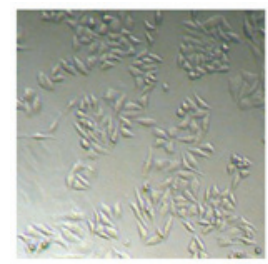

Control

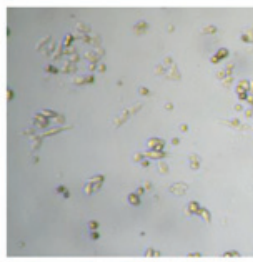

GPM $0.25 \mathrm{mg} / \mathrm{ml}$

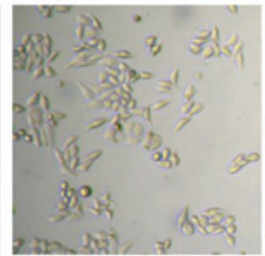

GPM $0.10 \mathrm{mg} / \mathrm{ml}$

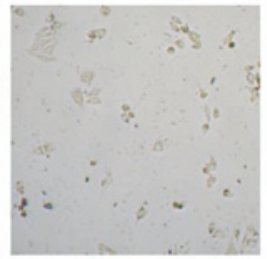

GPM $0.30 \mathrm{mg} / \mathrm{ml}$

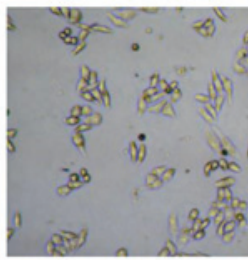

GPM $0.15 \mathrm{mg} / \mathrm{ml}$

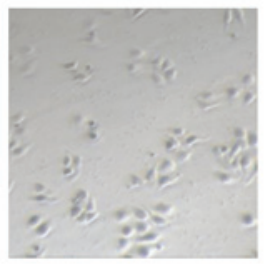

$5-\mathrm{Fu} 0.003 \mathrm{mg} / \mathrm{ml}$

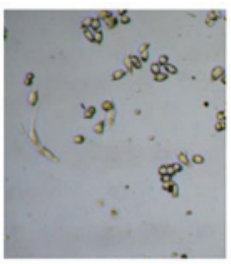

GPM $0.20 \mathrm{mg} / \mathrm{ml}$

Figure 2. Effect of GPM and 5-Fu on cell morphology under an inverted microscope (magnification, x100). GPM, gecko peptides mixture; 5-Fu, fluorouracil.

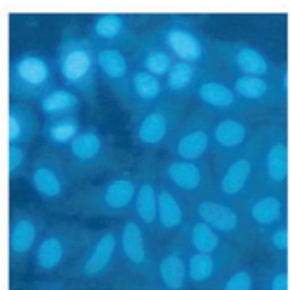

Control

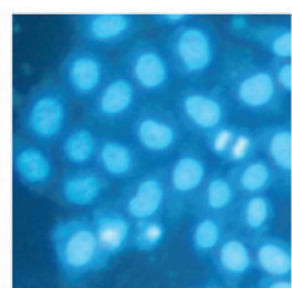

$5-\mathrm{Fu}$

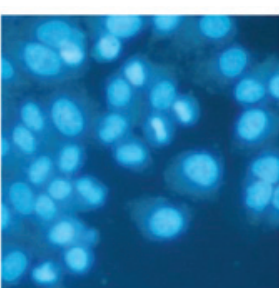

GPML

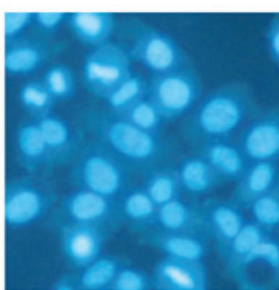

GPMH

Figure 3. Hoechst 33258 fluorescence staining in HepG2 cells (magnification, x400). Cells were treated with $0.003 \mathrm{mg} / \mathrm{ml} 5-\mathrm{Fu}, 0.06 \mathrm{mg} / \mathrm{ml} \mathrm{GPML}$ or $0.08 \mathrm{mg} / \mathrm{ml}$ GPMH for $24 \mathrm{~h}$. GPM, gecko peptides mixture; 5-Fu, fluorouracil.
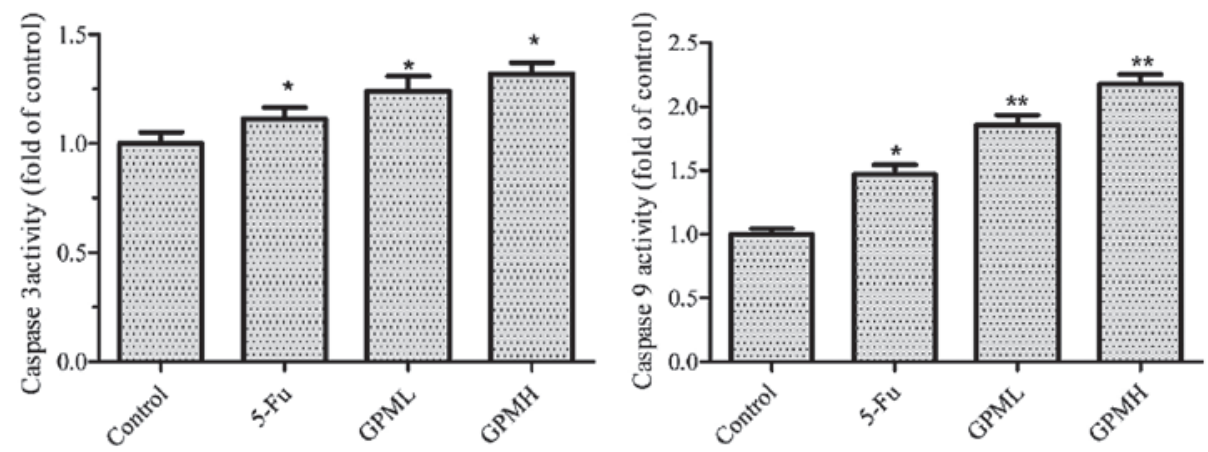

Figure 4. Effects of GPM on caspase-3 and caspase-9 activity. Cells were treated with $0.003 \mathrm{mg} / \mathrm{ml} 5-\mathrm{Fu}, 0.06 \mathrm{mg} / \mathrm{ml} \mathrm{GPML} \mathrm{or} 0.08 \mathrm{mg} / \mathrm{ml}$ GPMH for $24 \mathrm{~h}$ ${ }^{*} \mathrm{P}<0.05,{ }^{* *} \mathrm{P}<0.01$ vs. control group. GPM, gecko peptides mixture; 5-Fu, fluorouracil.

\section{Results}

GPM inhibits the proliferation of HepG2 cells. The effect of GPM on HepG2 cell growth was assessed by the MTT assay. The results showed that GPM significantly inhibited the proliferation of HepG 2 cells in a dose- and time-dependent manner (Fig. 1). After treatment with GPM for 24,48 or $72 \mathrm{~h}$, the values of $\mathrm{IC}_{50}$ were $0.154,0.133$ and $0.051 \mathrm{mg} / \mathrm{ml}$, respectively. The cells treated with GPM exhibited rounded morphology, shrinkage and attachment loss (Fig. 2).

Effects of GPM on nuclear morphology. The apoptotic morphology of cells was identified by Hoechst 33258 staining. As shown in Fig. 3, morphological changes in

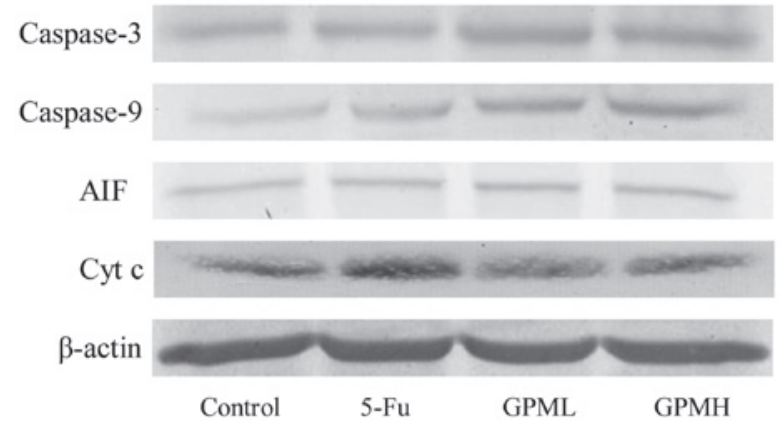

Figure 5. Effects of GPM on the expression levels of caspase-3, caspase-9, AIF, Cyt $c$ and $\beta$-actin. Cells were treated with $0.003 \mathrm{mg} / \mathrm{ml} 5-\mathrm{Fu}, 0.06 \mathrm{mg} / \mathrm{ml}$ GPML or $0.08 \mathrm{mg} / \mathrm{ml}$ GPMH. GPM, gecko peptides mixture; 5-Fu, fluorouracil; AIF, apoptosis-inducing factor; Cyt $c$, cytochrome $c$. 

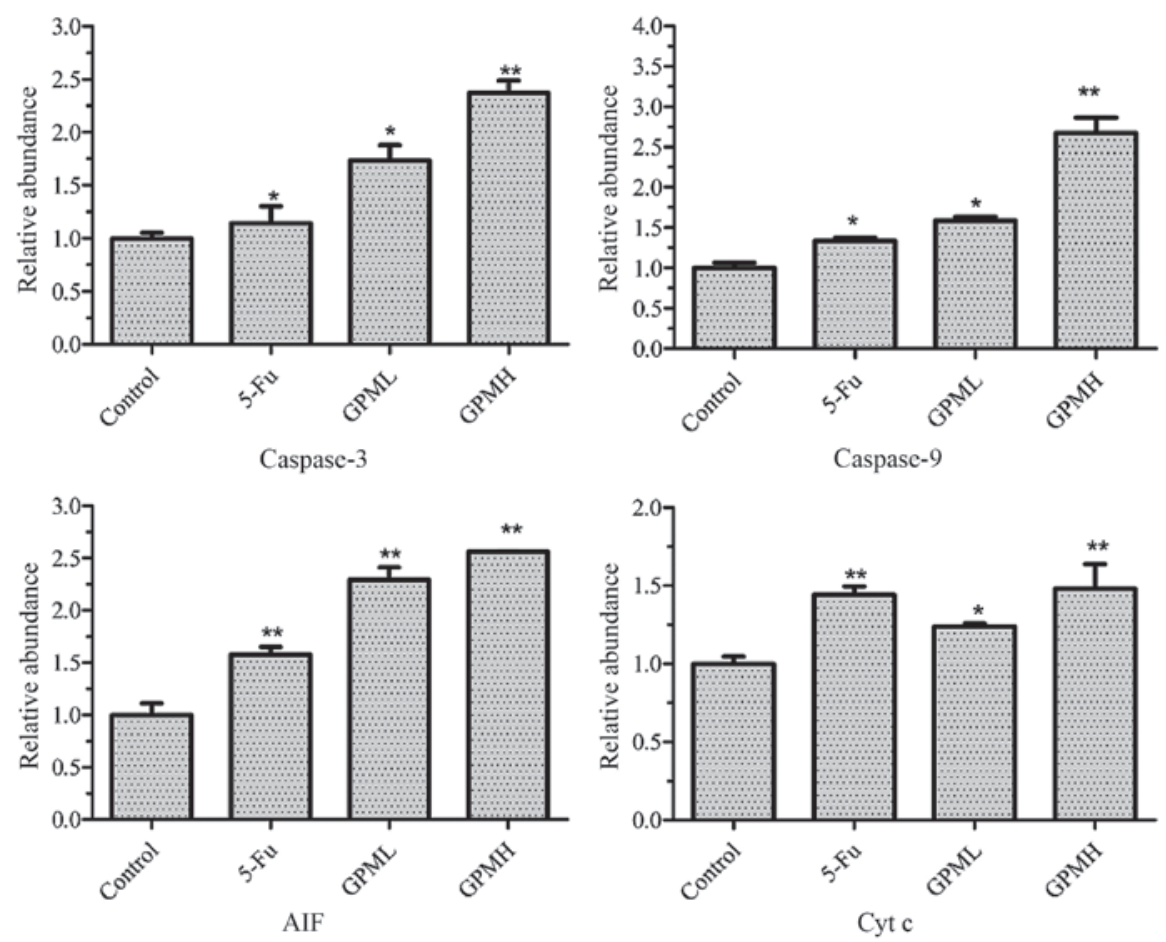

Figure 6. Effect of GPM on caspase-3 and caspase-9 expression levels and the release of AIF and Cyt $c$ from the mitochondria into the cytosol. "P<0.05, ${ }^{* *} \mathrm{P}<0.01$ vs. control group. Cells were treated with $0.003 \mathrm{mg} / \mathrm{ml} 5-\mathrm{Fu}, 0.06 \mathrm{mg} / \mathrm{ml} \mathrm{GPML}$ or $0.08 \mathrm{mg} / \mathrm{ml} \mathrm{GPMH}$. ${ }^{*} \mathrm{P}<0.05,{ }^{* *} \mathrm{P}<0.01$ vs. control group. GPM, gecko peptides mixture; 5-Fu, fluorouracil; AIF, apoptosis-inducing factor; Cyt $c$, cytochrome $c$.

apoptotic characteristics, such as nuclear condensation, chromosomal condensation and granular apoptotic bodies in GPM-treated cells were also observed by fluorescence microscopy.

Effects of GPM on caspase activity. As the initiators and executors of cell death, cysteine proteases have an important role in the apoptotic process (12). As shown in Fig. 4, GPM treatment caused a significant dose-dependent increase in caspase- 3 and caspase- 9 activity, suggesting an apoptotic effect of GPM in HepG2 cells.

Effects of GPM on expression levels of apoptotic proteins. As shown in Fig. 5, western blotting demonstrated that the release of Cyt $c$ and AIF from the mitochondria to cytosol increased, while the expression levels of caspase- 3 and caspase- 9 were upregulated by GPM treatment in a dose-dependent manner. The changes in the proteins were significantly different when compared with the control group (Fig. 6) $(\mathrm{P}<0.05)$.

\section{Discussion}

Over recent decades, the incidence of cancer has increased markedly, which causes serious damage to human health (13). Although contemporary therapeutic strategies have shown evident anticancer ability, severe side effects remain unavoidable. The search for new antitumor agents that are more effective but less toxic has attracted increasing attention (14). Extracting peptides from natural medicines for cancer therapy has been extensively reported worldwide and is promising in cancer treatment. Peptides could have a role in various ways, such as inhibiting the proliferation of tumors, arresting the cell cycle, suppressing tumor angiogenesis, and inducing apoptosis (15). Gecko has been widely used in traditional Chinese medicine for hundreds of years. In our previous studies, the gecko crude peptides showed effective antitumor activity on H22-bearing mice and the HepG2 cell line $(16,17)$. However, the effects of GPM on human hepatocytes remain to be elucidated. Therefore, the aim of the present study was to further reveal the underlying molecular mechanism by which GPM induces apoptosis in the human HCC cell line HepG2.

In the present study, the MTT assay revealed that GPM could inhibit the growth of HepG2 cells in a dose- and time-dependent manner. Further experiments demonstrated that this inhibition was due to GPM treatment, which induced dose-dependent cell death with typical morphological changes. These data suggest that GPM may be a potentially effective agent for cancer treatment. Using Hoechst 33258 staining, it was demonstrated that the cell death induced by GPM in HepG2 cells, which belongs to apoptosis, for the caspase-3 and caspase-9 expression levels was increased following GPM treatment. Western blotting analysis also showed that GPM could stimulate the release of Cyt $c$ and AIF from the mitochondria into the cytosol, suggesting that GPM-induced apoptosis in HepG2 cells is mediated by the mitochondrial apoptotic pathway.

Apoptosis is the major control mechanism by which cells die under numerous conditions, such as incorrect repair of DNA damage (18). This self-destructive cellular process is critical for organ development, tissue remodeling, immune regulation and several disease conditions (19). Numerous antitumor agents exert their therapeutic effects by inducing apoptosis (20-24). Mitochondria have an essential role 
in the regulation of cell apoptosis, and there are certain proteins that are closely associated with cell apoptosis in the intermembrane (25).

The mitochondrial ultrastructure is normal during cell apoptosis, but its function has significantly changed. Mitochondrial dysfunction induces the opening of the mitochondrial permeability transition pores and releases mitochondrial apoptogenic proteins, such as AIF (26) and Cyt $c$ (27). Normally, the AIF and Cyt $c$ proteins are located in the intermembrane space of mitochondria, while under the action of various AIFs, they are released from the mitochondria to the cytoplasm. AIF is finally transferred to the nucleus, causing the characteristic changes of apoptosis. AIF was the first protein discovered that mediated caspase-independent cell death (28). Cyt $c$ is released into the cytosol and induces caspase-dependent apoptosis, leading to the activation of caspases and apoptosis $(29,30)$. AIF could increase apoptotic signals by promoting mitochondrial release of Cyt $c$. Although apoptosis induced by AIF is not dependent on caspase, there is a cross action, synergy and even antagonism among AIF, caspase and Cyt $c$. Owing to various death signals and cell types, the regulation of cell apoptosis is actually accomplished through various interactions and the whole signal network, which require further study.

Caspase, a family of cysteine proteases, is an integral section of the apoptotic pathway. The induction of apoptosis is associated with the activation of caspase (31). Caspase-3 is in the downstream of cell apoptosis, and caspase- 9 is the apical caspase in the mitochondria-initiated apoptosis pathway (32). Activation of caspase- 3 is correlated with activation of caspase-9 (33). The release of Cyt $c$ triggers the activation of caspase-9 through the formation of the apoptosome. Subsequent activation of the initiator caspase- 9 causes the cleavage of effector caspase-3, which subsequently activates DNase and causes DNA fragmentation in the nucleus (34). In summary, caspase-3 is an executioner caspase that can be activated by the following mitochondrial pathway involving the activation of caspase- 9 due to the release of Cyt $c$ to the cytosol (35), finally causing programmed cell death.

In conclusion, the GPM possibly induced apoptotic cell death in HepG2 cells by activating the mitochondrial apoptotic pathway. These results demonstrate that GPM may be a potential therapeutic agent for the treatment of HCC.

\section{Acknowledgements}

The present study was supported by a grant from the Key Programs for Science and Technology Development of Henan Province (no. 142102310031).

\section{References}

1. Abrams P and Marsh JW: Current approach to hepatocellular carcinoma. Surg Clin North Am 90: 803-816, 2010.

2. But DY,Lai CL and Yuen MF: Natural history of hepatitis-related hepatocellular carcinoma. World J Gastroenterol 14: 1652-1656, 2008.

3. Faivre S, Bouattour M and Raymond E: Novel molecular therapies in hepatocellular carcinoma. Liver Int 31 (Suppl 1): 151-160, 2011.

4. Kang TH, Bang JY, Kim MH, Kang IC, Kim HM and Jeong HJ: Atractylenolide III, a sesquiterpenoid, induces apoptosis in human lung carcinoma A549 cells via mitochondria-mediated death pathway. Food Chem Toxicol 49: 514-519, 2011.
5. Liao N, Ao M, Zhang P and Yu L: Extracts of Lycoris aurea induce apoptosis in murine sarcoma S180 cells. Molecules 17: 3723-3735, 2012

6. Wang YX, Gu XX, Geng D, Sun HY, Wang CM, Jiang GX, Hou XN and Ma CH: Differentiation of bel-7402 human hepatocarcinoma cells induced by aqueous extracts of fresh gecko (AG) and its anti-tumor activity in vivo. J Ethnopharmacol 155: 1583-1588, 2014.

7. Song P: Wang XM and Xie S: Experimental study on mechanisms of lyophilized powder of fresh gekko Chinenis in inhibiting H22 hepatocarcinoma angiogenesis. Zhongguo Zhong Xi Yi Jie He Za Zhi 26: 58-62, 2006 (In Chinese).

8. Yang JX and Wang XM: Progress study and research on treating tumor of Gecko. Chinese Journal of Digestion 14: 2428-2431, 2006.

9. Wu BD: Treatment of 105 cases of esophagus tumor by compound recipe of Gecko. Zhongguo Zhongxiyi Jiehe Za Zhi 19: 502, 1999 (In Chinese).

10. Song Y, Wang JG, Li RF, Li Y, Cui ZC, Duan LX and Lu F: Gecko crude peptides induce apoptosis in human liver carcinoma cells in vitro and exert antitumor activity in a mouse ascites H22 xenograft model. J Biomed Biotechnol 2012: 743573, 2012.

11. Cui CC: Research of antitumor effect of Gecko ethanol extract II. Henan University of Science and Technology, 2013 (In Chinese).

12. Jiang CP, Ding H, Shi DH, Wang YR, Li EG and Wu JH: Pro-apoptotic effects of tectorigenin on human hepatocellular carcinoma HepG2 cells. World J Gastroenterol 18: 1753-1764, 2012.

13. Olefson S and Moss SF: Obesity and related risk factors in gastric cardia adenocarcinoma. Gastric Cancer 18: 23-32, 2015.

14. Wang N, Tan HY, Li L, Yuen MF and Feng Y: Berberine and Coptidis Rhizoma as potential anticancer agents: Recent updates and future perspectives. J Ethnopharmacol 176: 35-48, 2015.

15. Costantino VV, Lobos-Gonzalez L, Ibañez J, Fernandez D, Cuello-Carrión FD, Valenzuela MA, Barbieri MA, Semino SN, Jahn GA, Quest AF and Lopez LA: Dehydroleucodine inhibits tumor growth in a preclinical melanoma model by inducing cell cycle arrest, senescence and apoptosis. Cancer Lett 372: 10-23, 2016.

16. Xu XL, Wang JG, Li RF, Li SP, Qiu XJ and Duan LX: Inhibitory effect of Gecko peptides mixture on growth of human esophageal squamous carcinoma cell line EC109 cells. Zhongguo Lin Chuang Yao Li Xue Za Zhi 29: 602-604, 2013.

17. Song Y, Wang JG, Cui CC, Qian X, Li RF, Duan LX, Liu L and Xi SM: Apoptotic mechanism of gecko crude peptides on human liver carcinoma cell line HepG2. Zhong Yao Cai 35: 863-866, 2012 (In Chinese).

18. Lowe SW and Lin AW: Apoptosis in cancer. Carcinogenesis 21: 485-495, 2000.

19. Bhatia D, Mandal A, Nevo E and Bishayee A: Apoptosis-inducing effects of extracts from desert plants in HepG2 human hepatocarcinoma cells. Asian Pac J Trop Biomed 5: 87-92, 2015.

20. Li CJ, Huang SY, Wu MY, Chen YC, Tsang SF, Chyuan JH and Hsu HY: Induction of apoptosis by ethanolic extract of Corchorus olitorius leaf in human hepatocellular carcinoma (HepG2) cells via a mitochondria-dependent pathway. Molecules 17: 9348-9360, 2012.

21. Yang B, Wang YQ, Cheng RB, Chen JL, Chen J, Jia LT and Zhang RS: Induction of cytotoxicity and apoptosis in human gastric cancer cell SGC-7901 by isovaltrate acetoxyhydrin isolated from Patrinia heterophylla bunge involves a mitochondrial pathway and G2/M phase cell cycle arrest. Asian Pac J Cancer Prev 14: 6481-6486, 2013.

22. Kim TM, Shin SK, Kim TW, Youm SY, Kim DJ and Ahn B. Elm tree bark extract inhibits HepG2 hepatic cancer cell growth via pro-apoptotic activity. J Vet Sci 13: 7-13, 2012.

23. Nho KJ, Chun JM and Kim HK: Ethanol Extract of Dianthus chinensis L. induces apoptosis in human hepatocellular carcinoma HepG2 cells in vitro. Evid Based Complement Alternat Med 2012: 573527, 2012.

24. Li L, Chen GG, Lu YN, Liu Y, Wu KF, Gong XL, Gou ZP, Li MY and Liang NC: Ent-11 $\alpha$-Hydroxy-15-oxo-kaur-16-en-19-oic-acid inhibits growth of human lung cancer A549 cells by arresting cell cycle and triggering apoptosis. Chin J Cancer Res 24: 109-115, 2012.

25. Cao MR, Li Q, Liu ZL, Liu HH, Wang W, Liao XL, Pan YL and Jiang JW: Harmine induces apoptosis in HepG2 cells via mitochondrial signaling pathway. Hepatobiliary Pancreat Dis Int 10: 599-604, 2011. 
26. Susin SA, Lorenzo HK, Zamzami N, Marzo I, Snow BE, Brothers GM, Mangion J, Jacotot E, Costantini P, Loeffler M, et al: Molecular characterization of mitochondrial apoptosis-inducing factor. Nature 397: 441-446, 1999.

27. Liu X, Kim CN, Yang J, Jemmerson R and Wang X: Induction of apoptotic program in cell-free extracts: Requirement for dATP and cytochrome c. Cell 86: 147-157, 1996.

28. Norberg E, Orrenius S and Zhivotovsky B: Mitochondrial regulation of cell death: Processing of apoptosis-inducing factor (AIF). Biochem Biophys Res Commun 396: 95-100, 2010.

29. Chandra D, Liu JW and Tang DG: Early mitochondrial activation and cytochrome c up-regulation during apoptosis. J Biol Chem 277: 50842-50854, 2002.

30. Zhang P, Xu Y, Li L, Jiang Q, Wang M and Jin L: In vitro protective effects of pyrroloquinoline quinone on methylmercury-induced neurotoxicity. Environ Toxicol Pharmacol 27: 103-110, 2009.

31. Li LK, Rola AS, Kaid FA, Ali AM and Alabsi AM: Goniothalamin induces cell cycle arrest and apoptosis in $\mathrm{H} 400$ human oral squamous cell carcinoma: A caspase-dependent mitochondrial-mediated pathway with downregulation of NF- $\kappa \beta$. Arch Oral Biol 64: 28-38, 2016.
32. Li Y, Hu J, Huang $\mathrm{H}$ and He Y: Effect of Jinlong capsule on proliferation and apoptosis of human pancreatic cancer cells BxPC-3. J Tradit Chin Med 33: 205-210, 2013.

33. Du RH, Cui JT, Wang T, Zhang AH and Tan RX: Trichothecin induces apoptosis of HepG2 cells via caspase-9 mediated activation of the mitochondrial death pathway. Toxicon 59: 143-150, 2012.

34. Kang $\mathrm{MH}$ and Reynolds CP: Bcl-2 Inhibitors: targeting mitochondrial apoptotic pathways in cancer therapy. Clin Cancer Res 15: 1126-1132, 2009.

35. Jin Q, Nan JX and Lian LH: antitumor activity of leaves from potentilla discolor on human hepatocellular carcinoma cell line HepG-2. Chin J Nat Med 9: 61-64, 2011. 